\title{
Genital herpes
}

A M Geretti

Sex Transm Infect 2006;82(Suppl IV):iv31-iv34. doi: 10.1136/sti.2006.023200

G enital herpes (GH) is the fourth most common sexually transmitted infection diagnosed at genitourinary medicine (GUM) clinics in the United Kingdom. ${ }^{1}$ There are two herpes simplex virus (HSV) types; HSV-2 is almost entirely associated with genital disease whereas HSV$\mathrm{l}$ is associated with both oropharyngeal and genital disease. In some, ${ }^{2-7}$ although not all, ${ }^{8}$ areas of the United Kingdom HSV- 1 accounts for more than 50\% of first episodes of GH. Differentiating between HSV types yields important prognostic information. Genital infection with HSV-1 shows a milder natural history than infection with HSV-2 and both symptomatic recurrences and subclinical shedding are less frequent. ${ }^{9-16}$

GH is classified as primary when an HSV seronegative person acquires HSV-1 or HSV-2; initial non-primary when a person with antibody against one virus type acquires the opposite type; and recurrent. Primary and initial infections are often asymptomatic or unrecognised, but can become symptomatic at any time. ${ }^{912} 14$ Thus a first episode of GH may represent a recently acquired or a long lasting infection. Most asymptomatic individuals with HSV-2 subsequently develop symptomatic disease. ${ }^{14}$

$\mathrm{GH}$ is a lifelong infection that can cause substantial morbidity to those infected and have serious consequences, including neonatal herpes and increased risk for HIV acquisition and transmission. ${ }^{17}$ As clinical signs and symptoms are often subtle, most infections are unrecognised and undiagnosed. ${ }^{18} 19$ Infected people shed the virus intermittently, regardless of whether lesions are clinically apparent. ${ }^{15}$

\section{RECOMMENDED TESTS}

Screening of asymptomatic GUM clinic attendees by either HSV antibody testing (evidence level IV, recommendation grade $\mathrm{C})^{20-24}$ or HSV detection in genital specimens (evidence level IIa, recommendation grade $\mathrm{B})^{18}{ }^{20}$ is not recommended at present, although this area is under active review.

\section{HSV antibody testing}

Testing for HSV type specific antibodies can be used to diagnose HSV infection in asymptomatic people. ${ }^{18} 20$

HSV-2 antibodies are indicative of GH. HSV-l antibodies do not differentiate between genital and oropharyngeal infection. ${ }^{18}$

Arguments in favour of serological screening include:

- HSV-2 infection rates are as high as or higher than those of other STIs for which screening is in place..$^{1825}$

- People with asymptomatic or undiagnosed infection may transmit HSV to sexual partners or neonates. ${ }^{202627}$

- Behavioural changes, condom use, and suppressive antiviral therapy reduce the risk of HSV transmission. ${ }^{28-30}$

- Vaccines may soon become available to protect HSV seronegative people from infection and disease. ${ }^{31}$

- HSV-2 seropositive people who engage in high risk sexual behaviour can be counselled about the increased risk of HIV acquisition (evidence level Ia, recommendation grade A). ${ }^{17}$
Arguments against screening include:

- The specificity and sensitivity of current antibody assays are $<100 \%{ }^{32}{ }^{33}$

- False positive results generate unnecessary psychological morbidity.

- False positive and false negative results lead to inappropriate counselling.

- Counselling of HSV-2 seronegative HSV-1 seropositive people is problematic, given the large proportion of $\mathrm{GH}$ caused by HSV-1. ${ }^{2-7}$

Assays should be used that detect antibodies against the antigenically unique glycoproteins gGl and gG2 (evidence level III, recommendation grade B). ${ }^{18} 3233$

- Western blot (WB) is the diagnostic gold standard. It is more than $97 \%$ sensitive and more than $98 \%$ specific, but is labour intensive and not commercially available. ${ }^{18}$

- Several commercial assays have become available. ${ }^{33}{ }^{34}$ Well validated in-house assays have also been developed. ${ }^{35}$ Among commercial assays, the HerpeSelect-1 and HerpeSelect-2 ELISA IgG, and HerpeSelect 1 and 2 Immunoblot IgG (Focus Technology, CA, USA) have been approved by the American Federal Drug Administration. In sexually active adults, sensitivity and specificity of enzyme linked immunosorbent assay (ELISA) relative to $\mathrm{WB}$ are $91 \%$ and $92 \%$ for HSV-1 and $96 \%$ and $97 \%$ for HSV-2, respectively. Immunoblot sensitivity and specificity are $99 \%$ and $95 \%$ for HSV-1 and $97 \%$ and $98 \%$ for HSV-2, respectively. ${ }^{36}$

- HSV seroprevalence rates in the local population and the presence or absence of risk factors for GH influence the positive predictive value of HSV type specific antibody assays. Local epidemiological data and patient demographic characteristics should guide testing and result interpretation (evidence level III, recommendation grade B). ${ }^{24} 32$

- In patients with a low likelihood of GH, a positive HSV-2 result should be confirmed in a repeat sample or by using a different assay (evidence level III, recommendation grade B) ${ }^{32}$

- Type specific antibody can take months to develop and false negative results may occur early after infection. ${ }^{32}$ In first episode disease the diagnostic use of type specific antibody testing will require follow up samples after 3 months to demonstrate seroconversion.

\section{Direct detection of HSV in genital lesions}

Methods should be used that directly demonstrate HSV in swabs or scrapings from a lesion (evidence level Ia, recommendation grade A). ${ }^{20} 3738$

Abbreviations: EIA, enzyme immunoassay; ELISA, enzyme linked immunosorbent assay; GH, genital herpes; GUM, genitourinary medicine; HSV, herpes simplex virus; IFA, immunofluorescence assay; $\mathrm{PCR}$, polymerase chain reaction; $\mathrm{WB}$, western blot 
Cytological examination (Tzanck and Papanicolaou smears) has modest diagnostic specificity and sensitivity and should not be relied upon for diagnosis (evidence level Ib, recommendation grade A). ${ }^{938}$

HSV isolation in cell culture is the diagnostic gold standard and the current routine diagnostic method in the United Kingdom. ${ }^{39}$ Isolates can be typed and tested for antiviral susceptibility. Virus culture is slow, labour intensive, and expensive. Specificity is virtually $100 \%$, but levels of virus shedding, quality of specimens, and transport conditions influence sensitivity. ${ }^{90-42}$ First episode ulcers more often yield the virus than recurrent lesions ( $82 \%$ versus $43 \%$ ). ${ }^{9}$ Average sensitivity is $52-93 \%$ for vesicles, $41-72 \%$ for ulcers, and $19-27 \%$ for crusted lesions. ${ }^{90}$ Delayed sample processing and lack of specimen refrigeration after collection and during transport significantly reduce the yield of virus culture. ${ }^{41}$

HSV DNA detection by polymerase chain reaction (PCR) increases HSV detection rates by $11-71 \%$ compared with virus culture. ${ }^{370-48}$ HSV PCR is widely available in UK virology laboratories for testing of cerebrospinal fluid in patients with neurological disease. ${ }^{39}$ There have been at least 14 large studies comparing virus culture with PCR for the detection of HSV in mucocutaneous swabs, together comprising data from over 3500 patients. These studies demonstrated that the relative sensitivity of virus culture averaged $70 \%$ and ranged between $25 \%$ and $89 \%$. PCR should be implemented, after local validation, as the preferred diagnostic method for GH (evidence level $\mathrm{Ib}$, recommendation grade A). ${ }^{370-48}$

Unlike virus culture, PCR based methods do not rely on virus growth and may allow less stringent conditions for sample storage and transport.

Real time PCR assays allow detection and typing of HSV in a single reaction tube, with faster turn around times (potentially 2 hours) and lower risk of contamination than traditional PCR assays. ${ }^{42}$ The RealArt HSV 1/2 PCR kit (Artus, Germany) is commercially available for use in real time assays.

Viral antigen can be detected by direct immunofluorescence assay (IFA) using fluorescein labelled monoclonal antibodies on smears, or by enzyme immunoassay (EIA) on swabs.

IFA shows lower sensitivity (74\%) and specificity (85\%) than virus culture and cannot be recommended (evidence level Ia, recommendation grade A). ${ }^{49}$

Commercially available EIAs (for example, HerpChek, PerkinElmer, Belgium) show $\geqslant 95 \%$ specificity and $62-100 \%$ sensitivity relative to virus culture. $.^{43-45} 50-54$ Sensitivity may be higher than virus culture for typical presentations and late specimens, but lower for cervical or urethral swabs and recurrent episodes. ${ }^{43-45}$ 50-54 HerpChek does not differentiate between HSV types.

\section{RECOMMENDED SITES FOR TESTING}

- Clotted blood (if serology indicated)

- Lesion material (if lesion is present).

\section{FACTORS THAT ALTER TESTS RECOMMENDED OR SITES TESTED}

- Genital lesions that could be caused by HSV (direct detection)

- Serological screening should be considered in people with a history of recurrent genital symptoms of unknown aetiology when direct virus detection methods (virus culture or PCR testing of genital specimens) have been repeatedly negative (evidence level III, recommendation grade B). ${ }^{18}{ }^{21-24}$
- Patients who are known contacts: serological screening should be considered for sexual partners of people with $\mathrm{GH}$, where there is a concern about transmission. Some couples may find that their HSV status is concordant. Discordant couples can identify strategies to prevent transmission (evidence level III, recommendation grade B). ${ }^{20-24} 32$

\section{Risk groups}

- Homosexual men: no alteration to standard recommendation

- Sex workers: no alteration to standard recommendation

- Young patients: HSV-2 antibody tests should not be used in children < 14 years of age because of a high false positive rate (evidence level III, recommendation grade B). ${ }^{32}$

\section{Other groups}

- Pregnant women: routine screening of pregnant women, and their partners, to identify those already infected and those at risk of infection remains controversial. ${ }^{55}$ The identification of serologically discordant couples may offer the opportunity to counsel seronegative women about strategies to prevent infection during pregnancy (evidence level III, recommendation grade B). ${ }^{20} 2156-58$ Screening of pregnant women is recommended where there is a history of genital herpes in the partner (evidence level III, recommendation grade B). ${ }^{56-58}$

- Women with a history of hysterectomy: no alteration to standard recommendation.

\section{RECOMMENDATION FOR FREQUENCY OF REPEAT TESTING}

- In people with a low likelihood of infection, a positive HSV-2 antibody result should be confirmed in a repeat sample or by using a different assay.

- Repeat testing of HSV seronegative women with seropositive male partners may be helpful in pregnancy.

- The decision about repeat testing should be guided by the patient's history of potential exposure.

- In patients with a suspected recent infection who test HSV antibody negative early after presentation, repeat serological testing is recommended after 3 months as seroconversion may be delayed. ${ }^{32}$

- Repeat direct testing for HSV in genital specimens is not indicated in the presence of typical recurrent HSV lesions as long as viral detection and typing were successfully accomplished during a previous episode.

\section{RECOMMENDATION FOR A TEST OF CURE}

Not recommended.

\section{STAKEHOLDER INVOLVEMENT}

BASHH Herpes Special Interest Group (at time of writing): Dr Simon Barton, Dr David Brown, Dr Frances Cowen, Dr Susan Drake, Dr Anna Maria Geretti, Dr John Green, Dr James Hickling, Dr George Kinghorn, Dr Patricia Munday, Ms Marian Nicholson, Dr Raj Patel, Dr Anne Scoular, Dr Derek Timmins, Dr Mark Whitaker, Dr Paul Woolley.

\section{RIGOUR OF DEVELOPMENT}

MeSH: "Herpes-genitalis-diagnosis," "Herpes-simplex-diagnosis," "Sensitivity," "Specificity" (1983 to April 2004). Further evidence was obtained from the International 
Herpes Management Forum guidelines ${ }^{59}$ and the 2002 Center for Disease Control STI treatment guidelines. ${ }^{60}$

\section{APPLICABILITY}

HSV type specific antibody assays may not be available in all laboratories.

\section{AUDITABLE OUTCOME MEASURES}

- HSV antibody tests that do not discriminate between virus types should not be used for the diagnosis of GH. Target $100 \%$

- In HSV-2 seropositive people with a low likelihood of infection, a positive HSV-2 result should be confirmed in a repeat sample or by using a different assay. Target 100\%.

Conflict of interest: The Herpes Special Interest Group is a special interest group of the MSSVD, currently sponsored by an educational grant from GlaxoSmithKline. Members have undertaken research and been funded to attend meetings by GlaxoSmithKline

I gratefully acknowledge the help of David Brown, Virus Reference Division, Central Public Health Laboratory, Colindale, London. Susan Drake, Department of Sexual Medicine, Birmingham Heartlands Hospital, Birmingham. George Kinghorn, Department of Genitourinary Medicine, Royal Hallamshire Hospital, Sheffield. Patricia Munday, Watford Sexual Health Centre, Watford General Hospital, Watford.

Before submission this guideline was distributed to all members of the Herpes Special Interest Group. Their comments were noted and incorporated into the current document.

Correspondence to: A M Geretti, Department of Virology, Royal Free Hospital, London NW3 2QG, UK; a.geretti@medsch.ucl.ac.uk

Accepted for publication 31 August 2006

\section{REFERENCES}

1 www.hpa.org.uk/infections/topics_az/hiv_and_sti/sti-1, herpes/ epidemiology/epidemiology.htm (last accessed April 2004).

2 Woolley PD, Kudesia G. Incidence of herpes simplex virus type- 1 and type-2 from patients with primary (first-attack) genital herpes in Sheffield. Int $J$ STD AIDS 1990; 1:184-6.

3 Ross JD, Smith IW, Elton RA. The epidemiology of herpes simplex types 1 and 2 infection of the genital tract in Edinburgh 1978-1992. Genitourin Med 1993:69:381-3.

4 Tayal SC, Pattman RS. High prevalence of herpes simplex virus type 1 in female anogenital herpes simplex in Newcastle upon Tyne 1983-92. Int J STD AIDS 1994;5:359-61.

5 Slomka MJ, Emery L, Munday PE, ef al. A comparison of PCR with virus isolation and direct antigen detection for diagnosis and typing of genital herpes. J Med Virol 1998;55:177-83.

6 Thompson C. Genital herpes simplex typing in genitourinary medicine: 19951999. Int J STD AIDS 2000;11:501-2.

7 Scoular A, Norrie J, Gillespie G, et al. Longitudinal study of genital infection by herpes simplex virus type 1 in Western Scotland over 15 years. BMJ 2002;324:1366-7.

8 Ramaswamy M, McDonald C, Sabin C, et al. The epidemiology of genital infection with herpes simplex virus type 1 (HSV-1) and type 2 (HSV-2) in genitourinary medicine attendees in inner London. Sex Transm Infect 2005;81:306-8.

9 Corey L, Holmes KK. Genital herpes simplex virus infections: current concepts in diagnosis, therapy, and prevention. Ann Intern Med 1983;98:973-83.

10 Lafferty WE, Coombs RW, Benedetti J, et al. Recurrences after oral and genital herpes simplex virus infection. Influence of site of infection and viral type. N Engl J Med 1987;316:1444-9.

11 Benedetti J, Corey L, Ashley R. Recurrence rates in genital herpes after symptomatic first-episode infection. Ann Intern Med 1994; 121:847-54

12 Langenberg AG, Corey L, Ashley RL, et al. A prospective study of new infections with herpes simplex virus type 1 and type 2. Chiron HSV Vaccine Study Group. N Engl J Med 1999;341:1432-8.

13 Benedetti JK, Zeh J, Corey L. Clinical reactivation of genital herpes simplex virus infection decreases in frequency over time. Ann Intern Med 1999:131:14-20.

14 Wald A, Zeh J, Selke S, et al. Reactivation of genital herpes simplex virus type 2 infection in asymptomatic seropositive persons. N Engl J Med 2000;342:844-50.

15 Koelle DM, Wald A. Herpes simplex virus: the importance of asymptomatic shedding. J Antimicrob Chemother 2000;45(Suppl T3):1-8.

16 Engelberg R, Carrell D, Krantz E, et al. Natural history of genital herpes simplex virus type 1 infection. Sex Transm Dis 2003;30:174-7.

17 Wald A, Link K. Risk of human immunodeficiency virus infection in herpes simplex virus type 2-seropositive persons: a meta-analysis. J Infect Dis 2002; 185:45-52.
18 Ashley RL, Wald A. Genital herpes: review of the epidemic and potential use of type-specific serology. Clin Microbiol Rev 1999;12:1-8.

19 Cowan FM, Johnson AM, Ashley R, et al. Relationship between antibodies to herpes simplex virus (HSV) and symptoms of HSV infection. J Infect Dis 1996; 174:470-5.

20 Wald A. Testing for genital herpes: how, who, and why. Curr Clin Top Infect Dis 2002;22:166-80

21 Munday PE, Vuddamalay J, Slomka MJ, et al. Role of type specific herpes simplex virus serology in the diagnosis and management of genital herpes. Sex Transm Infect 1998;74:175-8

22 Kinghorn GR. Type-specific serological testing for herpes simplex infection. Int J STD AIDS 1998;9:497-500.

23 Malkin JE. Herpes simplex virus. Who should be tested. Herpes 2002:9:31.

24 Copas AJ, Cowan FM, Cunningham AL, et al. An evidence based approach to testing for antibody to herpes simplex virus type 2. Sex Transm Infect 2002;78:430-4.

25 Smith JS, Robinson NJ. Age-specific prevalence of infection with herpes simplex virus types 2 and 1: a global review. J Infect Dis 2002;186/Suppl 1):S3-28.

26 Mertz GJ, Schmidt $O$, Jourden JL, et al. Frequency of acquisition of firstepisode genital infection with herpes simplex virus from symptomatic and asymptomatic source contacts. Sex Transm Dis 1985;12:33-9.

27 Kimberlin DW. Advances in the treatment of neonatal herpes simplex infections. Rev Med Virol 2001;11:157-63.

28 Newton EA, Kuder JM. A model of the transmission and control of genital herpes. Sex Transm Dis 2000;27:363-70.

29 Corey L. Challenges in genital herpes simplex virus management. J Infect Dis 2002;186(Suppl 1):S29-33.

30 Corey L, Wald A, Patel R, et al. Once daily valaciclovir to reduce the risk of transmission of genital herpes. N Engl J Med 2004;350:11-20.

31 Stanberry LR, Spruance SL, Cunningham AL, et al. Glycoprotein-D-adjuvant vaccine to prevent genital herpes. N Engl J Med 2002;347:1652-61.

32 Ashley RL. Performance and use of HSV type-specific serology test kits. Herpes 2002;9:38-45

33 Morrow RA, Friedrich D, Krantz E. Performance of the Focus and Kalon enzyme-linked immunosorbent assays for antibodies to herpes simplex virus type 2 glycoprotein G in culture-documented cases of genital herpes. J Clin Microbiol 2003;41:5212-4

34 Van Dyck E, Buve A, Weiss HA, et al. Performance of commercially available enzyme immunoassays for detection of antibodies against herpes simples virus type 2 in African populations. J Clin Microbiol 2004:42:2961-5.

35 Gopal R, Gibbs T, Slomka MJ, et al. A monoclonal blocking EIA for herpes simplex virus type 2 antibody: validation for seroepidemiological studies in Africa. J Virol Methods 2000;87:71-80.

36 www.herpeselect.com (accessed December 2002).

37 Scoular A. Using the evidence base on genital herpes: optimising the use of diagnostic tests and information provision. Sex Transm Infect 2002;78:160-5.

38 Koutsky LA, Stevens CE, Holmes KK, et al. Underdiagnosis of genital herpes by current clinical and viral-isolation procedures. N Engl J Med 1992;326:1533-9.

39 Geretti AM, Brown WD. National survey of diagnostic services for genital herpes. Sex Transm Infect 2005;81:316-7.

40 Scoular A, Gillespie G, Carman WF. Polymerase chain reaction for diagnosis of genital herpes in a genitourinary medicine clinic. Sex Transm Infect 2002;78:21-5

41 Wald A, Huang ML, Carrell D, et al. Polymerase chain reaction for detection of herpes simplex virus (HSV) DNA on mucosal surfaces: comparison with HSV isolation in cell culture. J Infect Dis 2003;188:1345-51.

42 Ramaswamy M, McDonald C, Smith M, et al. Diagnosis of genital herpes by real-time PCR in routine clinical practice. Sex Transm Infect 2004;80:406-10.

43 Slomka MJ, Emery L, Munday PE, et al. A comparison of PCR with virus isolation and direct antigen detection for diagnosis and typing of genital herpes. J Med Virol 1998;55:177-83.

44 Koenig M, Reynolds KS, Aldous W, et al. Comparison of Light-Cycler PCR, enzyme immunoassay, and tissue culture for detection of herpes simplex virus. Diagn Microbiol Infect Dis 2001;40:107-10.

45 Burrows J, Nitsche A, Bayly B, et al. Detection and subtyping of herpes simplex virus in clinical samples by LightCycler PCR, enzyme immunoassay and cell culture. BMC Microbiol 2002;2:12.

46 Aldea C, Alvarez CP, Folgueira L, et al. Rapid detection of herpes simplex virus DNA in genital ulcers by real-time PCR using SYBR green I dye as the detection signal. J Clin Microbiol 2002;40:1060-2.

47 Van Doornum GJ, Guldemeester J, Osterhaus AD, et al. Diagnosing herpesvirus infections by real-time amplification and rapid culture. J Clin Microbiol 2003;41:576-80.

48 Schmutzhard J, Merete Riedel H, Zweygberg Wirgart B, et al. Detection of herpes simplex virus type 1, herpes simplex virus type 2 and varicella-zoster virus in skin lesions. Comparison of real-time PCR, nested PCR and virus isolation. J Clin Virol 2004;29:120-6.

49 Lafferty WE, Krofft S, Remington M, et al. Diagnosis of herpes simplex virus by direct immunofluorescence and viral isolation from samples of external genita lesions in a high-prevalence population. J Clin Microbiol 1987;25:323-6.

50 Baker DA, Pavan-Langston D, Gonik B, et al. Multicenter clinical evaluation of the Du Pont Herpchek HSV ELISA, a new rapid diagnostic test for the direct detection of herpes simplex virus. Adv Exp Med Biol 1990;263:71-6.

51 Gleaves CA, Rice DH, Lee CF. Evaluation of an enzyme immunoassay for the detection of herpes simplex virus (HSV) antigen from clinical specimens in viral transport media. J Virol Methods 1990;28:133-9.

52 Kudesia G, Van Hegan A, Wake S, et al. Comparison of cell culture with an amplified enzyme immunoassay for diagnosing genital herpes simplex infection. J Clin Pathol 1991;44:778-80. 
53 Sillis $\mathrm{M}$. Clinical evaluation of enzyme immunoassay in rapid diagnosis of herpes simplex infections. J Clin Pathol 1992;45:165-7.

54 Cone RW, Swenson PD, Hobson AC, et al. Herpes simplex virus detection from genital lesions: a comparative study using antigen detection (HerpChek) and culture. J Clin Microbiol 1993:31:1774-6.

55 Rouse DJ, Stringer JSA. An appraisal of screening for maternal type-specific herpes simplex antibodies to prevent neonatal herpes. Am J Obstet Gynecol 2000;183:400-6

56 Brown ZA, Selke S, Zeh J, et al. The acquisition of herpes simplex virus during pregnancy. N Engl J Med 1997;337:509-15.
57 Kinghorn GR. Debate: the argument for. Should all pregnant women be offered type-specific serological screening for HSV infection? Herpes 2002;9:46-7.

58 Brown ZA, Wald A, Morrow RA, et al. Effect of serologic status and cesarean delivery on transmission rates of herpes simplex virus from mother to infant. JAMA 2003;289:203-9.

59 www.ihmf.org/guidelines/summary7.asp\#Genital HSV (accessed Dec 2002)

60 Centers for Disease Control and Prevention. Sexually transmitted diseases treatment guidelines 2002. MMWR 2002;51:12-7. 